УДК 340.132

DOI https://doi.org/10.32837/pyuv.v1i4(29).392

\author{
B. О. Панкратова \\ orcid.org/0000-0002-4775-565X \\ кандидат юридичних наук, \\ доиент кафедри юридичних дисииплін \\ Сулської філії \\ Харківського національного університету внутрішніх справ
}

\title{
ТОЧНІСТЬ ЯК ВИМОГА ДО ЗМІСТУ НОРМАТИВНО-ПРАВОВОГО АКТА
}

Постановка проблеми. Нормативно-правові акти є засобом врегулювання суспільних відносин, вирішення завдань і реалізації функцій держави. Тому важливо, щоб їхній зміст був точним і чітким, що є основою для їх однакового застосування та робить суспільні відносини стабільними і підвищує довіру до органів державної влади, адже нечіткість, двозначність, суперечливість норм права призводить до зниження ефективності правового регулювання, необмеженого розсуду у процесі правозастосування i, як результат, свавілля, невіри громадян у закон.

Аналіз основних досліджень і публікацій. Окремі вимоги до нормативно-правового акта, зокрема точності, висвітлені у працях Л.В. Ажнюк, С.Д. Бражника, I.О. Билі-Сабадаш, Н.М. Касаткиної, Т.В. Кашаніної, Д.А. Керімова, В.М. Косовича, Д.А. Монастирського, М.І. Панова, О.В. Пушняка, І.П. Сидорчука, А.С. Смітюх, О.О. Сухарьової, І.В. Суходубова, Л. Фулера та ін.

Метою статті $\epsilon$ аналіз точності як вимоги до нормативно-правових актів.

Виклад основного матеріалу дослідження. Слід зауважити, що ще римськими юристами були створені правила: leges intellegi ab omnibus debent - «закони повинні бути зрозумілими кожному»; ubi jus incertum, ibi nullum - «коли закон не визначений, він не існує», які є важливими і для сучасних правових систем.

Ідея точності закону була розвинута у фундаментальній праці Ш. Монтеск'є «Про дух законів». У книзі 26 «Про закони стосовно порядку речей, який вони визначають» розділ 16 присвячений тому, що слід мати на увазі при створенні законів. Так, Ш. Монтеск'є зазначає: стиль законів має бути зрозумілим і простим; пряме значення завжди зрозуміліше, ніж непряме; закони не повинні бути ледве вловимими; вони призначені для людей простого мислення; тож їхній рівень не вершини мистецтва логіки, а звичайнісінький розум сімейства; якщо немає потреби передбачати в законі винятки і застереження, то набагато ліпше буде їх уникати [8]. Таким чином, можна зробити висновок, що в цій праці Монтеск'є наголошував на точності, зрозумілості, простоті закону як важливих вимогах до нього.
У юридичній літературі завжди приділялася значна увага точності закону, яка не втрачає актуальності й на сучасному етапі. T.М. Назаренко висловлює думку, що правові норми, незважаючи на їхню абстрактність, повинні достатньо точно й виразно окреслювати життєві ситуації та давати жорстку формулу поведінки, що здебільшого не викликає сумнівів у моделі належної поведінки учасників правовідносин; формальна визначеність, властива юридичним нормам, дозволяє забезпечити належну організованість суспільних відносин: чіткість і конкретність прав і обов'язків ïх учасників [9, с. 48$]$.

Зрештою, точність акта покликана забезпечувати ефективність правового регулювання й гарантувати єдиний для всіх, стійкий правопорядок. I, навпаки, невизначеність змісту правових норм допускає можливість необмеженого розсуду в процесі реалізації права, що неминуче провокує розбіжності, суперечливі інтерпретації, суперечки, правові конфлікти [3, с. 27].

$\mathrm{y}$ юридичній літературі поширеним $є$ твердження про визначення «точності закону» як відповідності суджень законодавця мовній формі іх вираження в законодавчому тексті. Так М.І. Панов вказує, що поняття «точність», яке широко використовується у філософії, включає в себе гносеологічний, логічний, лінгвістичний і прагматичний аспекти (рівні) як її об’єктивні та необхідні показники. У своєму поєднанні вони можуть свідчити про точність (або, навпаки, неточність) правових норм i, відповідно, про ступінь досконалості закону [10, с. 12].

Гносеологічний аспект точності норм права означає те, що в законі в узагальненому вигляді вказані лише найбільш істотні й типові ознаки актів поведінки людини одного й того самого виду. Виокремлення загальних ознак - результат копіткої пізнавальної діяльності, що включає в себе методи як емпіричного вивчення відповідних об'єктів (спостереження, порівняння, експеримент, вимірювання), так і теоретичного дослідження (абстрагування, аналіз і синтез, індукцію та дедукцію, перехід від абстрактного до конкретного і навпаки тощо). Причому в цих ознаках має діалектично поєднуватися абстрактне і конкретне 
[10, с. 12-13]. Так, цивільне законодавство врегульовує договір у загальному вигляді шляхом закріплення основних положень (видових ознак), які точно визначають його зміст і властиві різним видам договору (наприклад, форма, ціна, момент укладення договору). Але, незважаючи на те, що положення сформульовані в загальному вигляді, вони точно відображають суттєві ознаки, які відрізняють один договір від іншого.

Логічний аспект вказує на його зв'язок із загальними законами та правилами формальної логіки й акцентує увагу на тому, що останні лежать в основі формулювання відповідних норм. Визначення в законі правових понять (дефініцій) мають бути об'ємними та водночас короткими. За загальним правилом, законодавець вдається до використання понять точного значення, які характеризуються формальною визначеністю, чіткістю, ї обсяг і зміст суворо фіксовані [10, с. 13].

Проекти нормативно-правових актів мають відповідати логічним вимогам, які досягаються шляхом дотримання логічних правил: тотожності; несуперечності; однозначності; логічної послідовності викладу тексту нормативно-правового акта; узгодженості; системності; недопустимості дублювання [6, с. 25-26].

Водночас варто відзначити, що нормативно-правові акти не можуть абсолютно чітко врегульовувати правові відносини. Тому доречно зазначає M.I. Козюбра про те, що абсолютна визначеність таких наслідків є недосяжною, а закон, який намагається їх визначити за допомогою надмірної жорсткості формулювань, швидко набуває рис «скам'янілості», тобто старіє. У зв'язку з цим важлива роль у впровадженні в життя принципу визначеності належить судовій практиці [5, с. 6].

Отже, нормативно-правовий акт повинен бути точним у межах, які є можливими при суспільних відносинах, що постійно змінюються. Тому в багатьох нормативно-правових актах використовують оціночні поняття («розумний строк», «поважні причини», «тяжка хвороба», «виняткові випадки»), чим законодавець надає юридичне значення необмеженому колу обставин, що виникають чи можуть виникнути в реальному житті [12, с. 163]. Використання в законі оціночних понять забезпечує динамізм права, його пристосування до суспільних відносин, що з часом змінюються.

Також слід зауважити на тому моменті, що вимога точності не є однаковою для всіх нормативно-правових актів залежно від їх юридичної сили та сфери застосування. Наприклад, зважаючи на установчий характер норм Конституції, вони повинні бути викладені точно, що зумовлює недопущення різного тлумачення її приписів. Водночас норми Конституції мають загальний характер, тому дещо меншою мірою є точними в деталях або конкретизації положень. Така теза підтверджу- ється практикою Конституційного Суду України, який вказав, що: наявність у Конституції України надто деталізованих положень, місце яким у поточному законодавстві, породжуватиме необхідність частого внесення змін до неї, що негативно позначатиметься на стабільності Основного Закону (Висновок від 2 червня 1999 р. № 2-в/99) [1].

Щодо сфер застосування, то слід підкреслити високу точність норм кримінального права, котрі визначають, яке діяння є злочином і яке має бути покарання за нього. Водночас норми, що врегульовують сімейні правовідносини, підвищеними вимогами до точності можуть і не володіти.

Логічний аспект точності вказує й на те, що при створенні нормативно-правового акта важливо дотримуватися законів логіки не тільки щодо текстуального змісту, а й розміщати текст у логічній послідовності, узгоджувати частини акта між собою. Прикладом логічної послідовності викладу тексту можуть слугувати кодифіковані акти. Так, Цивільний процесуальний кодекс України містить спочатку загальні положення (сторони процесу, докази тощо), а потім - різні види проваджень. Тому, щоб кожен раз за різних видів провадження не дублювати загальні положення, вони викладаються на початку акта.

Варто наголосити, що порушення логічного аспекту точності норми права при його застосуванні становиться проблемою. Погоджуємося з думкою Д.А. Керімова, який вважає, що порушення логіки закону, неточність його понять, формулювань, невизначеність використаних термінів породжує численні запити, тягне зміни і доповнення, різні тлумачення та роз'яснення, викликає непродуктивну витрату часу, сил та енергії, одночасно $€$ живильним грунтом для бюрократичної тяганини, дозволяє перекручувати зміст закону і неправильно його застосовувати $[4$, с. 55].

Лінгвістичний (семантичний) аспект означає, що терміни нормативно-правових актів оптимально відображають їх дійсний зміст. Це означає, що слова або словесні комплекси (словосполучення) повинні характеризуватися однозначністю, семантичною жорсткістю, чітко співвідноситися 3 поняттями, які вони призначені позначати. Терміни, що вживаються в нормах закону, незалежно від того, чи вони є загальнопоширеними, спеціально-юридичними, технічними або іншими, мають бути позбавлені експресивності, виступати особливими знаковими одиницями, що чітко концентрують в узагальненому вигляді [10, с. 14].

Прагматичний аспект точності нормативно-правового акта пов'язаний із дотриманням вимог (правил) юридичної техніки, яка забезпечує точність, чіткість, ясність, системність нормативно-правових актів. Так, П.М. Рабінович під юридичною технікою розуміє сукупність способів і прийомів, умінь і навичок формування всіх 
елементів механізму правового регулювання й ефективного оперування ними у праворегулятивній практиці [13, с. 145].

Зазвичай у навчальній юридичній літературі наводиться ряд правил до юридичної техніки, серед яких найбільш поширеними є такі:

- до змісту нормативно-правового акта, які полягають у повному відображені волі законодавця, урегулюванні однорідних суспільних відносин, логічній послідовності викладення нормативних приписів, відсутності прогалин і суперечностей як у самому нормативно-правовому акті, так і між різними актами, не допущенні дублювань положень нормативно-правових актів 3 одного й того самого питання тощо;

до мови викладення нормативно-правових актів: ясність, чіткість і простота мови нормативно-правових актів, точність і визначеність термінології, яка використовується.

O.В. Легка зауважує, що перелік загальних правил юридичної техніки не є вичерпним. У діючому правовому масиві важливо, щоб кожний юридичний документ мав реквізити, тобто такі зовнішні визначення, які б відображали предмет правового регулювання, сферу дії та інші параметри, що полегшують оперативний пошук і використання необхідної правової інформації: форма акта, назва, територіальний масштаб дії, місце та час прийняття, підписання, реєстраційний номер, а також відомості про посадову особу, котра підписала цей документ [7, с. 26].

Приєднуємося до думки науковця про важливість дотримання правил щодо зовнішнього оформлення нормативного акта. Також додамо, що для юридичної техніки важливим є дотримання вимог і до структури акта: назва - частини розділи - глави - статті - пункти - підпункти заключні та перехідні положення. Залежно від об’єму, призначення нормативного акта ці елементи можуть бути наявні в сукупності або лише основні з них, що визначаються змістом акта.

Важливим із погляду точності нормативно-правових актів є дотримання правил юридичної техніки, оскільки точність, ясність норм права дозволяє громадянам при вчиненні тієї чи іншої дії передбачити їх наслідки. Така прогнозованість наслідків є гарантією стабільності правового статусу особи. Навпаки, порушення таких правил, що виявляється в неточності понять і формулювань, невизначеності використаних термінів, як справедливо зазначають Н.В. Пильгун та А.С. Смітюх, призводять до змін і доповнень, численних запитів різних тлумачень і роз'яснень, спотворення змісту закону і неправильного його застосування [11, с. 43].

Вважаємо, що гносеологічний, логічний, лінгвістичний i прагматичний аспекти (рівні) точності норм є взаємопов’язаними. Їх поєднання у процесі правотворчості дозволяє створити нормативно-правовий акт, який буде містити точні, визначені положення, що дозволить оптимально застосовувати його на практиці.

На наш погляд, доречним є висновок, який робить професор M.I. Панов при аналізі визначеності кримінального закону. Науковець указує, що категорія «точність норм кримінального права» надає можливість реалізувати принцип правової визначеності у кримінальному праві, що, у свою чергу, забезпечує втілення на практиці принципів верховенства права і законності у кримінальному судочинстві як неодмінних ідей правової держави [10, с. 15]. Приєднуємося до цієї думки й додамо, що цей висновок $є$ актуальним і важливим для нормативно-правових актів у будь-якій галузі права.

Слід вказати, що невизначеність норми може бути основою для визнання іiі неконституційною. Наведемо як приклад Рішення Конституційного Суду України від 22 вересня 2005 р. № 5-рп/2005 у справі про постійне користування земельними ділянками. Суд визнав неконституційними положення п. 6 розд. $\mathrm{X}$ «Перехідні положення» Земельного кодексу України, у яких йдеться про переоформлення права власності або оренди громадянами та юридичними особами, які мають у постійному користуванні земельні ділянки, але за цим Кодексом не можуть мати їх на такому праві. Свою думку Суд, зокрема, мотивував невизначеним словосполученням «переоформити у встановленому порядку» без посилання на відповідні норми Кодексу або інших законів. У Кодексі та інших законах немає спеціальних норм щодо такого порядку переоформлення права постійного користування. Суд зазначив, що така невизначеність словосполучення ускладнює переоформлення і призводить до неоднозначної, довільної реалізації на практиці [14].

Така практика дозволяє зробити висновок, що точність є важливою вимогою, якій повинен відповідати нормативно-правовий акт.

На значимості якісного змісту закону у своїх рішеннях неодноразово наголошував Європейський суд з прав людини. Зокрема, його бачення полягає у такому: норма не може вважатися «законом», якщо вона не сформульована 3 достатньою мірою точності, що дозволяє особі погоджувати з нею свою поведінку, оскільки особа повинна мати можливість передбачати в розумних межах i стосовно до конкретних обставин ті наслідки, які може спричинити її поведінка. Передбачити 3 абсолютною точністю відповідні наслідки не обов'язково. Більше того, хоча визначеність формулювань бажана, необхідно уникати надмірної чіткості, оскільки право має властивість змінюватися залежно від розвитку суспільних відносин. (п. 31 Рішення по справі Гешмен і Герруп 
проти Сполученого Королівства від 25 листопада 1999 p.) [2].

Проведений аналіз дозволяє зробити висновок, що точність нормативно-правових актів у процесі правотворчості відіграє важливе значення, оскільки від рівня її ефективності безпосередньо залежить дотримання й захист прав людини, чітке правове регулювання. Визначеність нормативно-правових актів, в основу якої покладено вимогу точних формулювань законодавчих настанов, дозволяє громадянам при вчиненні тієї чи іншої дії передбачити наслідки, які можуть настати. Така прогнозованість є гарантією стабільності правового статусу особи, а отже, правової впевненості.

\section{Jimepamypa}

1. Висновок Конституційного Суду України від 2 червня 1999 р. № 2-в/99 у справі за зверненням Верховної Ради України щодо відповідності проекту Закону України «Про внесення змін до ст. 46 Конституції України» вимогам ст. 157 і 158 Конституції України. Вісник Конституиійного Суду України. 1999. № 3. С. 7.

2. Гешмен і Герруп проти Сполученого Королівства. Рішення Європейського суду з прав людини по справі від 25 листопада 1999 p. URL: http://search. ligazakon.ua/__doc2.nsf/link1/SO0564.html.

3. Демин А.В. Неопределенность в налоговом праве и правовые средства ее преодоления : дис. ... докт. юрид. наук : 12.00.04 / Московский гос. юрид. ун-т им. О.Е. Кутафина. Екатеринбург, 2014. 452 c.

4. Керимов Д.А. Законодательная техника : научно-методическое и учебное пособие. Москва : Норма : Инфра-М, 1998. $122 \mathrm{c.}$

5. Козюбра M.I. Принцип верховенства права та правової держави: єдність основних вимог. Наукові за писки НаУКМА. Серія «Юридичні науки». 2007. Т. 64. C. $3-9$.

6. Косович В. Логічні засоби забезпечення досконалості нормативно-правових актів України. Вісник Львівського ун-ту. Серія юридична. 2014. Вип. 59. С. 17-27.

7. Легка О.В. Взаємозв'язок правозастосовної техніки з іншими видами юридичної техніки. Науковий вісник Дніпропетровського державного університету внутрішніх справ. 2014. № 2. С. 23-29.

8. Монтеск'є ШI. Про дух законів. URL: http://www.lnu.edu.ua/faculty/ pravo/TG/spirit.pdf.

9. Назаренко Т.Н. Неопределенность в российском праве : дис. ... канд. юрид. наук : 12.00 .01 / Российская академия правосудия. Москва, 2006.213 с.

10. Панов M.I. Принцип правової визначеності у практиці Європейського суду з прав людини і проблеми якості кримінального законодавства України Проблеми законності : збірник наукових праць / відп. ред. В.Я. Тацій. Харків : Нац. юрид. ун-т ім. Ярослава Мудрого, 2015. Вип. 128. С. 8-19.

11. Пильгун Н.В. Перспективи вдосконалення юридичної техніки в Україні. Юридичний вісник. 2015. № 1. C. $42-46$.

12. Пресняков М. Дискреционные полномочия и правовая определенность. Власть. 2013. № 5. C. $163-166$.

13. Рабінович П.М. Основи загальної теорії права та держави : посібник. Київ, 1994.176 с.

14. Рішення у справі за конституційним поданням 51 народного депутата України щодо відповідно- сті Конституції України (конституційності) положень ст. 92, п. 6 розділу $\mathrm{X}$ «Перехідні положення» Земельного кодексу України (справа про постійне користування земельними ділянками). Вісник Конституиійного Суду України. 2005. № 5. С. 19.

\section{Анотація}

Панкратова В. О. Точність як вимога до змісту нормативно-правового акта. - Стаття.

У статті аналізуються така вимога до нормативно-правового акта, як точність. Стверджується, що визначеність права покликана забезпечувати ефективність правового регулювання й гарантувати єдиний для всіх, стійкий правопорядок. I, навпаки, невизначеність змісту правових норм допускає можливість необмеженого розсуду в процесі реалізації права, що неминуче провокує розбіжності, суперечливі інтерпретації, суперечки, правові конфлікти.

Наголошується на тому, що важливим і необхідним для визначеності нормативних актів $€$ те, що вони повинні точно вказувати на межі можливої та належної поведінки особи. Також визначеність норми повинна не допускати їі двозначності в розумінні та сприйнятті тими, кому вона адресується.

У статті розглядається гносеологічний, логічний, лінгвістичний і прагматичний аспекти точності нормативно-правового акта. Вказується, що гносеологічний аспект точності норм права означає те, що в законі в узагальненому вигляді вказані лише найбільш істотні й типові ознаки актів поведінки людини одного й того самого виду.

На думку автора, логічний аспект точності нормативно-правового акта вказує на його зв'язок із загальними законами та правилами формальної логіки. Визначення в законі правових понять (дефініцій) мають бути об'ємними та водночас короткими, із вказівкою всіх обов'язкових ознак, що вичерпно характеризують юридичні терміни. Лінгвістичний аспект означає, що терміни нормативно-правових актів оптимально відображають їх дійсний зміст. Тому слова або словосполучення повинні характеризуватися однозначністю, семантичною жорсткістю, чітко співвідноситися з поняттями, які вони призначені позначати. У свою чергу, прагматичний аспект точності нормативно-правового акта пов'язаний із дотриманням вимог (правил) юридичної техніки, яка забезпечує точність, чіткість, ясність, системність нормативно-правових актів.

Автор резюмує, що точність є важливою вимогою, якій повинен відповідати нормативно-правовий акт.

Ключові слова: нормативно-правовий акт, вимоги до нормативно-правових актів, чіткість, точність, логічність, визначеність.

\section{Summary}

Pankratova $V$. O. Accuracy as a requirement for the content of a legal act. - Article.

The article analyzes such a requirement for a legal act as accuracy. It is argued that the certainty of the right is intended to ensure the effectiveness of legal regulation and to guarantee a uniform and consistent law and order for all. Conversely, the ambiguity of the content of legal norms allows for unlimited discretion in the process of implementation of law, which inevitably provokes differences, conflicting interpretations, disputes, legal conflicts.

It is emphasized that it is important and necessary for the definition of regulations that they should accurately indicate the boundaries of possible and proper behavior of 
a person. Also, the certainty of a rule should not allow its ambiguity in the understanding and perception of those to whom it is addressed.

The article deals with epistemological, logical, linguistic and pragmatic aspects of the accuracy of a legal act. It is stated that the epistemological aspect of the accuracy of the norms of law means that the law summarizes only the most essential and typical features of acts of human behavior of the same kind.

According to the author, the logical aspect of the accuracy of a legal act indicates its relation to the general laws and rules of formal logic. The definitions of legal concepts (definitions) in the law should be voluminous and, at the same time, concise, indicating all the mandatory features that characterize the legal terms exhaustively.

It is noted that the linguistic aspect means that the terms of legal acts optimally reflect their true meaning. Therefore, words or phrases should be characterized by uniqueness, semantic rigidity, and clearly correlate with the concepts they are intended to denote. In turn, the pragmatic aspect of the precision of a legal act is connected with the observance of the requirements (rules) of legal technique, which ensures the accuracy, clarity, clarity, systematicity of legal acts.

The author summarizes that accuracy is an important requirement that a regulatory act must meet.

Key words: legal act, requirements to legal acts, clarity, accuracy, logic, certainty. 